\title{
Kluyveromyces lactis $\beta$-galactosidase immobilization in calcium alginate spheres and gelatin for hydrolysis of cheese whey lactose
}

\author{
Imobilização da $\beta$-galactosidase de Kluyveromyces lactis em esferas de alginato \\ de cálcio e gelatina para hidrólise da lactose presente no soro de queijo
}

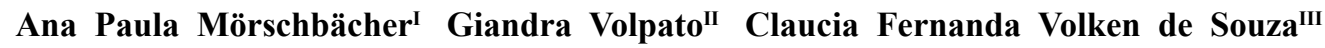

\section{ABSTRACT}

One of the greatest challenges for dairy industries is the correct destination of all the whey generated during cheese making, considering its high impact, the large volume created, and its technological potential. Enzymatic hydrolysis of cheese whey lactose is a biotechnological alternative. However, one of the limiting factors of its use is the relatively high cost of the enzymes, which could be lowered with the immobilization of these biocatalysts. Considering this context, the objective of this research was to evaluate the commercial Kluyveromyces lactis $\beta$-galactosidase enzyme immobilized in calcium alginate spheres and gelatin, using glutaraldehyde and concanavalin A (ConA) as modifying agents in the hydrolysis of cheese whey lactose process. Results have shown that the enzyme encapsulation complexed with ConA in alginate-gelatin spheres, without glutaraldehyde in the immobilization support, has significantly increased the hydrolysis of lactose rate, achieving a maximum conversion of $72 \%$.

Key words: lactose, cheese whey, $\beta$-galactosidase, enzyme
immobilization. RESUMO

Um dos grandes desafios das indústrias de laticínios é destinar de forma correta todo o soro gerado durante a produção de queijo, devido ao seu impacto ambiental, grande volume gerado e potencial tecnológico. A hidrólise enzimática da lactose presente no soro de queijo é uma alternativa biotecnológica. Contudo, um dos fatores limitantes de sua utilização é o custo relativamente alto das enzimas, o que poderia ser minimizado com a imobilização destes biocatalisadores. Baseado nesse contexto, o objetivo do presente trabalho foi avaliar a enzima comercial $\beta$-galactosidase de Kluyveromyces lactis, imobilizada em esferas de alginato de cálcio e gelatina, empregando o glutaraldeído e a concanavalina A (ConA) como agentes modificadores, no processo de hidrólise da lactose presente no soro de queijo. Os resultados obtidos demonstraram que o encapsulamento da enzima complexada com ConA em esferas de alginato-gelatina, sem a presença de glutaraldeído no meio de imobilização, aumentou de modo significativo o teor de hidrólise da lactose, obtendo conversão máxima de $72 \%$.

Palavras-chave: lactose, soro de queijo, $\beta$-galactosidase, imobilização de enzimas.

\section{INTRODUCTION}

Global production of cheese whey is approximately 200 millions tons/year, with an annual increase of about 2\% (ILLANES, 2011). Today, the dairy industry is seeking alternatives for using this whey; however, most of it is still disposed of as outflow in water treatment stations or directly in aquatic habitats. This situation creates a serious environmental problem due to the high concentration of organic compounds in the whey, which increase its biochemical oxygen demand (BOD), taking into account that lactose is responsible for more than $90 \%$ of this amount (KHIDER et al., 2004).

Treating whey at the stations is difficult as the number of biological systems capable of directly using lactose as a source of carbon is smaller when compared to the systems capable of metabolizing its monosaccharides (SISO, 1996). Furthermore, some preliminary processes that can treat cheese whey,

ICentro de Ciências Exatas e Tecnológicas. Centro Universitário UNIVATES, Lajeado, RS, Brasil

IIDepartamento de Biotecnologia, Instituto Federal do Rio Grande do Sul (IFRS), Campus Porto Alegre, Porto Alegre, RS, Brasil.

IIILaboratório de Biotecnologia de Alimentos, Programa de Pós-Graduação em Biotecnologia, Centro Universitário UNIVATES, Rua Avelino Tallini, 171, 95900-000, Lajeado, RS, Brasil. E-mail: claucia@univates.br. Corresponding author 
such as the ultrafiltration used to separate proteins and produce a concentrated product known as whey protein concentrate (WPC), are highly costly and generate a large volume of residue that is still lactoserich, and thus di not eliminate its final disposal problem (COTÉ et al., 2004).

Cheese whey is regarded as an important ingredient for food industry due to its high concentration of proteins with functional and nutritional characteristics (SMITHERS, 2008; TAVARES \& MALCATA, 2012). However, the use of cheese whey as a raw material is often limited by the presence of lactose (approximately $5 \% \mathrm{~m} / \mathrm{v}$ ), which presents a high tendency to absorb aromas and flavors, low solubility and sweetening power, besides intolerance problems (LADERO et al., 2001; PESSELA et al., 2003).

One alternative that may overcome these limitations is the hydrolysis of lactose, which allows for the attainment of products capable of reducing symptoms of lactose intolerance, as well as promotes technological improvements in the process, minimizing or even eliminating problems related to the low solubility and sweetening power of lactose. Another highly important benefit is the possibility of adding value to cheese whey, preventing its untreated disposal and/or decreasing costs associated with effluent treatment (PANESAR et al., 2010; ILLANES, 2011; PRAZERES et al., 2012).

The hydrolysis of lactose reaction may be catalyzed by acids or enzymes, such as $\beta$-galactosidase (EC 3.2.1.23), also known as lactase (VASILJEVIC \& JELEN, 2001). Over the last few decades, enzymatic hydrolysis has been raising greater interest as it is highly selective, maintains the characteristics of raw material in the yielded products, as well as its great potential for application in the food industry (ILLANES, 2011). However, despite the specificity and high catalyzing power of the enzymes, the direct application of these biocatalysts in industrial scale is limited by its relatively high cost. Other factors that encumber the use of enzymes are its solubility and low stability in operational conditions of industrial processes (GROSSOVÁ et al., 2008; PANESAR et al., 2010).

Enzyme immobilization is an important tool capable of rendering the application of these biocatalysts feasible in the second sector, as it allows reuse and may reduce its inactivation by means of temperature and organic solvents, improving the operational stability of the enzyme, which, in turn, enables the development of continuous operation systems. Furthermore, the immobilization eases the enzyme separation from the reaction environment and eliminates the risk of biocatalyst contaminating the final product (LÓPEZ-GALLEGO et al., 2005; GROSSOVÁ et al., 2008).

Currently, several techniques and supports have been developed and improved with the intent of optimizing enzyme immobilization for hydrolysis of lactose and enabling its application in the dairy industry. The use of low cost supports, such as alginate, gelatin, starches and agar is an important alternative to industrial use of immobilized enzymes. Nevertheless, these supports present limitations due to their low physical stability, which can be minimized with the use of crosslinking and linking agents, such as glutaraldehyde and concanavalin A (ConA) (HUSAIN \& SALEEMUDDIN, 1986; SALEEMUDDIN \& HUSAIN, 1991). Articles described in the literature have immobilized Aspergillus oryzae $\beta$-galactosidase using calcium alginate, gelatin and starch as supports, all treated with glutaraldehyde or ConA (HAIDER \& HUSAIN, 2007; HAIDER \& HUSAIN, 2009a; HAIDER \& HUSAIN, 2009b; FREITAS et al., 2011). In the dairy industry, due to the $\mathrm{pH}$-optimum of activity, A. oryzae $\beta$-galactosidase is the most suitable for hydrolysis of acid whey lactose. For the enzymatic treatment of milk and sweet whey, Kluyveromyces lactis $\beta$-galactosidase is more appropriate (HUSAIN, 2010; MLICHOVÁ \& ROSENBERG, 2006).

Within this context, the objective of this research was to evaluate the commercial $\boldsymbol{K}$. lactis $\beta$-galactosidase enzyme immobilized in calcium alginate spheres and gelatin, using glutaraldehyde and ConA as modifying agents in the process of hydrolysis of cheese whey lactose.

\section{MATERIALS AND METHODS}

Material

The $\boldsymbol{K}$. lactis $\beta$-galactosidase enzyme, Lactozym $^{\circledR}$ 3000L (Novozymes, Denmark), food grade, was donated by the Global Food Company (São Paulo, Brazil). ConA (VI-type), extracted from Canavalia ensiformis (jack bean), in lyophilized form was purchased from Sigma-Aldrich Co (USA). All of the remaining chemical products and reagents used presented analytical grade.

Preparation of alginate-gelatin spheres with the immobilized $\beta$-galactosidase enzyme

The calcium alginate and gelatin spheres were developed from modifications on the method proposed by FREITAS et al. (2011). A suspension containing calcium alginate $(3.3 \% \mathrm{~m} / \mathrm{v})$ and 
gelatin $(2.02 \% \mathrm{~m} / \mathrm{v})$ was prepared in distilled water at $80^{\circ} \mathrm{C}$. Afterwards, it was added $10 \mathrm{~mL}$ of a $\beta$-galactosidase solution with an enzymatic activity of $525 \mathrm{U}$ or $1050 \mathrm{U}$, diluted in a buffer solution of potassium phosphate $(0.1 \mathrm{M}$ and $\mathrm{pH} 7.0)$ to the suspension, which had been previously cooled to $35^{\circ} \mathrm{C}$. The resulting mixture was slowly dripped into a $0.05 \mathrm{M}$ calcium chloride solution with and another without glutaraldehyde $(3.64 \% \mathrm{v} / \mathrm{v})$ with the use of a disposable needle $(25 \times 7 \mathrm{~mm})$ inserted into a $5.0 \mathrm{~mL}$ syringe. The formation of alginategelatin spheres through electrostatic interaction was instantaneous. After ten minutes of contact with the immobilization support at $25^{\circ} \mathrm{C}$, the resulting biocatalyst was separated through a sieve and rinsed with a potassium phosphate buffering solution, being soon after used in the experiments with hydrolysis of cheese whey lactose. The enzymatic analysis pointed to a complete immobilization of the enzyme in the medium. After this process, the immobilized enzyme was kept at $4^{\circ} \mathrm{C}$.

Preparation of the ConA- $\beta$-galactosidase complex for immobilization in alginate-gelatin

In order to evaluate the influence of adding

ConA to the enzyme immobilization, we developed a complex from modifications to the method described by KHARE \& GUPTA (1988). We prepared two $\beta$-galactosidase enzyme solutions (1050U), one with the addition of $4 \mathrm{mg}$ ConA $\mathrm{mL}^{-1}$ of enzyme and another without it. This solution was refrigerated at $4{ }^{\circ} \mathrm{C}$ for $2 \mathrm{~h}$, with occasional agitations, and subsequently immobilized in the alginate-gelatin spheres, half being treated with glutaraldehyde $(3.64 \% \mathrm{v} / \mathrm{v})$ and half with no treatment. The spheres were used in the hydrolysis of cheese whey lactose experiments. The enzymatic analysis pointed to a complete immobilization of the enzyme in the medium. After this process, the immobilized enzyme was kept at $4^{\circ} \mathrm{C}$.

Hydrolysis of cheese whey lactose with immobilized $\beta$-galactosidase enzyme

It was added $250 \mathrm{~mL}$ of cheese whey reconstructed at $5 \%(\mathrm{~m} / \mathrm{v})$ of lactose to Erlenmeyer flasks. The enzymatic hydrolysis of lactose processes were performed using $\boldsymbol{K}$. lactis $\beta$-galactosidase immobilized in the alginate-gelatin spheres in an agitator with orbital-rotation movements (MA 830, Marconi, Piracicaba, São Paulo, Brazil) at $125 \mathrm{rpm}$ and $37^{\circ} \mathrm{C}$. After $0,30,60,120,180,240,300,360$, 480 , and 720 minutes of hydrolysis reaction, it was collected samples that were submitted at $100^{\circ} \mathrm{C}$ (MA 156, Marconi, Piracicaba, São Paulo, Brazil) for 5 minutes, to make the enzyme inactive, and afterwards we determined the glucose concentration. All the experiments were performed in triplicate. The cheese whey lactose conversion rate was calculated according to Equation 1:

$$
\text { Conversion rate }(\%)=\frac{C_{g l u} \times M M_{l a c}}{C i_{l a c} \times M M_{g l u}} \times 100
$$

Where: $\mathrm{C}_{\mathrm{glu}}$ is glucose concentration; $\mathrm{MM}_{\mathrm{lac}}$ is molar mass of lactose; $\mathrm{Ci}_{\mathrm{lac}}$ is initial lactose concentration; $\mathrm{MM}_{\mathrm{glu}}$ is molar mass of glucose.

Analytical determinations

The $\beta$-galactosidase enzyme activity was determined according to the methodology proposed by $\mathrm{RECH}$ et al. (1999), with modifications, using o-nitrophenyl- $\beta$-d-galactopyranoside (ONPG) as a substrate. One unit of enzymatic activity was defined as the amount of enzyme required to release $1 \mu \mathrm{mol}$ of o-nitrophenol per minute, under analysis conditions. The glucose concentration was measured with the oxidase-peroxidase colorimetric method, using the enzymatic kit for glucose determination (Labtest, Minas Gerais, Brazil) and absorbance reading in spectrophotometer (Genesys 10S UV-Vis, Thermo Scientific, USA) at $505 \mathrm{~nm}$. The glucose concentration was assessed based on a calibration curve. The analyses were performed in triplicate.

Statistical analysis of cheese whey lactose conversion rate

The statistical evaluation of the cheese whey lactose conversion was performed into glucose rate, in the different $\beta$-galactosidase immobilization conditions, through the Analysis of Variance (ANOVA), and verified the significance of the model through the F test. In the significant models, the averages were compared to one another through the Tukey test, to a significance level of $95 \%(\mathrm{P}<0.05)$.

\section{RESULTS AND DISCUSSION}

Table 1 shows cheese whey lactose conversion rate by the $\boldsymbol{K}$. lactis $\beta$-galactosidase enzyme (525U e 1050U) immobilized in alginategelatin spheres treated and not treated with glutaraldehyde, during a 720 minute period of hydrolysis reaction at $37^{\circ} \mathrm{C}$.

The cheese whey lactose conversion rate under the different conditions varied from $4.8 \%$ to $56 \%$, demonstrating that the tested parameters (glutaraldehyde as a crosslinking agent, enzyme concentration, and reaction time) influence the hydrolysis of lactose process. We observed that the increase in enzyme/medium 
Table 1 - Influence of glutaraldehyde and ConA use on cheese whey lactose conversion rate (\%) into glucose by the $\boldsymbol{K}$. lactis $\beta$ galactosidase enzyme immobilized in alginate and gelatin spheres.

\begin{tabular}{|c|c|c|c|c|c|c|}
\hline Reaction time (min) & $\mathrm{A}(\%)$ & $A^{\prime}(\%)$ & B (\%) & $\mathrm{B}^{\prime}(\%)$ & $\mathrm{C}(\%)$ & $\mathrm{D}(\%)$ \\
\hline 0 & $0.20 \pm 0.01$ & $0.20 \pm 0.01$ & $0.20 \pm 0.01$ & $0.20 \pm 0.01$ & $0.20 \pm 0.01$ & $0.20 \pm 0.01$ \\
\hline 30 & $11.94 \pm 0.04^{\mathrm{e}}$ & $4.80 \pm 0.02^{\mathrm{f}}$ & $32.30 \pm 0.10^{\mathrm{b}}$ & $12.33 \pm 0.06^{\mathrm{d}}$ & $18.87 \pm 0.08^{\mathrm{c}}$ & $43.06 \pm 0.13^{\mathrm{a}}$ \\
\hline 60 & $11.98 \pm 0.05^{\mathrm{e}}$ & $4.78 \pm 0.02^{\mathrm{f}}$ & $39.66 \pm 0.13^{b}$ & $15.58 \pm 0.04^{\mathrm{d}}$ & $18.95 \pm 0.07^{\mathrm{c}}$ & $52.03 \pm 0.06^{\mathrm{a}}$ \\
\hline 120 & $12.11 \pm 0.03^{\mathrm{e}}$ & $4.82 \pm 0.03^{\mathrm{f}}$ & $46.39 \pm 0.05^{\mathrm{b}}$ & $17.36 \pm 0.01^{\mathrm{d}}$ & $19.04 \pm 0.07^{\mathrm{c}}$ & $61.93 \pm 0.11^{\mathrm{a}}$ \\
\hline 180 & $12.21 \pm 0.06^{\mathrm{e}}$ & $4.88 \pm 0.03^{\mathrm{f}}$ & $49.69 \pm 0.08^{b}$ & $17.67 \pm 0.01^{\mathrm{d}}$ & $19.11 \pm 0.03^{\mathrm{c}}$ & $66.33 \pm 0.06^{\mathrm{a}}$ \\
\hline 240 & $12.23 \pm 0.02 \mathrm{e}$ & $4.90 \pm 0.03^{\mathrm{f}}$ & $49.88 \pm 0.05^{\mathrm{b}}$ & $18.19 \pm 0.01^{\mathrm{d}}$ & $19.18 \pm 0.03^{\mathrm{c}}$ & $68.14 \pm 0.11^{\mathrm{a}}$ \\
\hline 300 & $12.26 \pm 0.03^{\mathrm{e}}$ & $4.96 \pm 0.02^{\mathrm{f}}$ & $54.37 \pm 0.10^{\mathrm{b}}$ & $18.35 \pm 0.01^{\mathrm{d}}$ & $19.18 \pm 0.07^{\mathrm{c}}$ & $68.17 \pm 0.17^{\mathrm{a}}$ \\
\hline 360 & $12.29 \pm 0.05^{\mathrm{e}}$ & $5.00 \pm 0.02^{\mathrm{f}}$ & $54.40 \pm 0.13^{\mathrm{b}}$ & $19.00 \pm 0.01^{\mathrm{d}}$ & $19.22 \pm 0.07^{\mathrm{c}}$ & $70.39 \pm 0.06^{\mathrm{a}}$ \\
\hline 480 & $12.33 \pm 0.03^{\mathrm{e}}$ & $5.02 \pm 0.03^{\mathrm{f}}$ & $56.12 \pm 0.05^{\mathrm{b}}$ & $19.33 \pm 0.01^{\mathrm{c}}$ & $19.23 \pm 0.01^{\mathrm{d}}$ & $70.76 \pm 0.13^{\mathrm{a}}$ \\
\hline 720 & $12.36 \pm 0.06^{\mathrm{d}}$ & $5.07 \pm 0.01^{\mathrm{f}}$ & $56.25 \pm 0.08^{\mathrm{b}}$ & $10.01 \pm 0.01^{\mathrm{e}}$ & $19.29 \pm 0.07^{\mathrm{c}}$ & $71.42 \pm 0.17^{\mathrm{a}}$ \\
\hline
\end{tabular}

*Averages with different superscripts in the same line differ statistically at $95 \%$ of significance $(\mathrm{P}<0.05)$, according to the Tukey test. The conditions applied were: (A) with glutaraldehyde in the immobilization support, without complexed ConA to the enzyme and 1050U of immobilized enzyme; (A') with glutaraldehyde, without ConA and 525U; (B) without glutaraldehyde, without ConA and 1050U; (B') without glutaraldehyde, without ConA and 525U; (C) with glutaraldehyde, with ConA and 1050U; (D) without glutaraldehyde, with ConA and $1050 \mathrm{U}$.

ratio and the absence of glutaraldehyde increased the conversion rate approximately ten-fold. Condition $\mathrm{B}$, in which the alginate-gelatin medium containing $1050 \mathrm{U}$ of the $\beta$-galactosidase enzyme immobilized without glutaraldehyde presented the highest whey lactose conversion rate.

When glutaraldehyde was used as a crosslinking agent in the immobilization medium, the lactose conversion rate was lower for both enzyme concentrations used. This might be due to the high reactivity of glutaraldehyde, which favors the formation of links between the enzyme and the support, and might distort the enzyme active core, leading to a decrease or loss of enzymatic activity during the immobilization process, which impairs substrate propagation (ALONSO et al., 2005; BETANCOR et al., 2006).

VIEIRA (2009) encapsulated the Kluyveromyces fragilis $\beta$-galactosidase enzyme in chitosan, alginate, and agar gels that were infused with different concentrations of glutaraldehyde. According to the author, a concentration of $0.50 \%$ glutaraldehyde in the immobilization medium may be enough to induce the distortion of the enzyme active site.

After 360 minutes of reaction (Table 1), when using the $\beta$-galactosidase enzyme (1050U) immobilized in alginate-gelatin spheres without glutaraldehyde in the immobilization medium (Condition B), the whey lactose conversion rate was approximately of $54 \%$. This result was higher than the one obtained by ESCOBAR et al. (2014), who immobilized $\boldsymbol{K}$. lactis $\beta$-galactosidase in calcium alginate spheres and achieved a maximum lactose conversion of $40 \%$ during the same reaction time. The highest conversion obtained in this research may be attributed to the use of gelatin, which decreased swelling of the alginate spheres, minimizing the leaching of the enzyme from the support to the external medium (SHEN et al., 2011).

However, even when using gelatin in the formation of spheres, it was not obtained high lactose conversion rates (Table 1). The analysis of enzymatic activity of $\boldsymbol{K}$. lactis $\beta$-galactosidase immobilized in alginate and gelatin spheres after the hydrolysis process has shown that approximately $18 \%$ of the enzyme was lost due to the leaching process. To bypass this problem, it was used complexed ConA to the enzyme before immobilization and checked the influence of this complex in the hydrolysis process of cheese whey lactose. The lactose conversion results obtained in these experiments are presented in table 1.

The use of complexed ConA to the enzyme before immobilization caused an increase of 7 and $15 \%$, with glutaraldehyde (Conditions A and C) and without glutaraldehyde (Conditions B and D), respectively, in the whey lactose conversion rate after a $720 \mathrm{~min}$ of reaction. The use of ConA significantly increased $(\mathrm{P}<0.05)$ the cheese whey lactose conversion in all evaluated reaction times, reaching a maximum conversion of about $72 \%$ (Condition D: $1050 \mathrm{U}$ of $\beta$-galactosidase enzyme complexed with ConA and immobilized in alginate-gelatin spheres without glutaraldehyde). 
The results obtained (Table 1) indicate that a small amount of ConA was enough to yield a nonsoluble complex, decreasing enzyme leaching after the hydrolysis process to about $3 \%$, and significantly increasing lactose conversion rate. HAIDER \& HUSAIN (2007) observed a similar effect when complexing the $A$. oryzae $\beta$-galactosidase enzyme with ConA and its later immobilization in calcium alginate spheres. In their research they used $\beta$-galactosidase immobilized in three different conditions: no treatment, complexed with ConA, and cross-linked with glutaraldehyde previously complexed with ConA, for the hydrolysis of a lactose solution, and, after 180 minutes of reaction, the conversion rates were 66,78 , and $89 \%$, respectively.

In a different study, HAIDER \& HUSAIN (2009a) evaluated the hydrolysis process of cheese whey lactose employing the same immobilized complex in alginate and starch spheres cross-linked with glutaraldehyde. The authors did not observe the total hydrolysis of lactose $(89 \%$ after 300 minutes of reaction). Complete hydrolysis using the $\beta$-galactosidase enzyme is rarely achieved due to galactose inhibition, a reaction byproduct, and due to the generation of a lactose isomer, known as allolactose (HAIDER \& HUSAIN, 2007).

There results previously obtained by HAIDER \& HUSAIN (2007) and HAIDER \& HUSAIN (2009a), concerning hydrolysis of lactose when compared to those of the present research, are due to a different source of the $\beta$-galactosidase enzyme and to the reduced effect of glutaraldehyde in the distortion of the A. oryzae enzyme active site.

\section{CONCLUSION}

The results obtained indicate that the immobilization of the $\boldsymbol{K}$. lactis $\beta$-galactosidase enzyme is a biotechnological and effective alternative for reducing the amount of lactose present in cheese whey, and the most appropriate conditions for the hydrolysis reaction were the encapsulation of the complexed enzyme with ConA in calcium alginate spheres and gelatin, without the presence of glutaraldehyde in the immobilization support. The employed process requires more studies with the intent of improving enzymatic immobilization by encapsulation for the hydrolysis of lactose and widening its application in an industrial scale, thus minimizing the great environmental problem involving the disposal of cheese whey, as well as adding value to this significant by product of the dairy industry.

\section{ACKNOWLEDGMENTS}

To Conselho Nacional de Desenvolvimento Científico e Tecnológico (CNPq) for the scholarships, to Unidade Integrada Vale do Taquari de Ensino Superior (UNIVATES) for the financial support granted for this research and to Prozyn Company for donating the enzymes

\section{REFERENCES}

ALONSO, N. et al. Immobilization and stabilization of glutaryl acylase on aminated sepabeads supports by the glutaraldehyde crosslinking method. J Mol Catal B-Enzym, v.35, p.57-61, 2005. Available from: $<$ http://www.sciencedirect.com/science/article/pii/ S1381117705000822>. Accessed: Mar. 12, 2015. doi: 10.1016/j. molcatb.2005.05.007

BETANCOR, L. et al. Different mechanisms of protein immobilization on glutaraldehyde activated supports: effect of support activation and immobilization conditions. Enzyme Microb Tech, v.39, p.877-882, 2006. Available from: <http:// www.sciencedirect.com/science/article/pii/S0141022906000317>. Accessed: Mar. 15, 2015. doi: 10.1016/j.enzmictec.2006.01.014.

COTÉ, A. et al. Hydrolysis of lactose in whey permeate for subsequent fermentation to ethanol. J Dairy Sci, v.87, p.16081620, 2004. Available from: <http://www.sciencedirect.com/ science/article/pii/S0022030204733159>. Accessed: Mar. 20, 2015. doi: 10.1016/j.enzmictec.2006.01.014.

ESCOBAR, G.P. et al. Avaliação de $\beta$-galactosidase livre e imobilizada na hidrólise da lactose do permeado de soro de queijo. Cad Ped, v.11, p.117-129, 2014. Available from: <http://www. univates.br/revistas/index.php/cadped/article/viewFile/973/565>. Accessed: Mar. 15, 2015.

FREITAS, F.F. et al. A comparison of the kinetic properties of free and immobilized Aspergillus oryzae $\beta$-galactosidase. Biochem Eng J, v.58-59, p.33-38, 2011. Available from: <http://www. sciencedirect.com/science/article/pii/S1369703X11002257>. Accessed: Mar. 27, 2015. doi: 10.1016/j.bej.2011.08.011.

GROSSOVÁ, Z. et al. Perspectives and applications of immobilised $\beta$-galactosidase in food industry - a review. Czech J Food Sci, v.26, p.1-14, 2008. Available from: <http://www.agriculturejournals.cz/ publicFiles/00808.pdf>. Accessed: Mar. 15, 2015.

HAIDER, T.; HUSAIN, Q. Calcium alginate entrapped preparations of Aspergillus oryzae $\beta$-galactosidase: Its stability and applications in the hydrolysis of lactose. Int J Biol Macromol, v.41, p.72-80, 2007. Available from: <http://www.sciencedirect.com/science/ article/pii/S0141813007000062>. Accessed: Mar. 17, 2015. doi: 10.1016/j.ijbiomac.2007.01.001.

HAIDER, T.; HUSAIN, Q. Immobilization of b-galactosidase by bioaffinity adsorption on concanavalin A layered calcium alginatestarch hybrid beads for the hydrolysis of lactose from whey/milk. Int Dairy J, v.19, p.172-177, 2009a. Available from: <http:/ www.sciencedirect.com/science/article/pii/S0958694608001763>. Accessed: Mar. 10, 2015. doi: 10.1016/j.idairyj.2008.10.005.

HAIDER, T.; HUSAIN, Q. Hydrolysis of milk/whey lactose by $\beta$-galactosidase: A comparative study of stirred batch process and packed bed reactor prepared with calcium alginate entrapped enzyme. Chem Eng Process: Process Intensification, v.48, 
p.576-580, 2009b. Available from: <http://www.sciencedirect. com/science/article/pii/S0255270108000445>. Accessed: Mar. 15, 2015. doi: 10.1016/j.cep.2008.02.007.

HUSAIN, Q. $\beta$-Galactosidases and their potential applications: a review. CRC Crit Rev Biotechnol, v.30, p.41-62, 2010. Available from: $<$ http://www.tandfonline.com/doi/full/10.3 109/07388550903330497>. Accessed: Mar. 17, 2015. doi: $10.3109 / 07388550903330497$.

HUSAIN,Q.; SALEEMUDDIN, M. Immobilization of glycoenzymes using crude concanavalin A and glutaraldehyde. Enzyme Microb Technol, v.8, p.686-690, 1986. Available from: <http://www. sciencedirect.com/science/article/pii/0141022986900670>. Accessed: Mar. 27, 2015. doi: 10.1016/0141-0229(86)90067-0.

ILLANES, A. Whey upgrading by enzyme biocatalysis. Electronic J Biotechnol, v.14, p.1-28, 2011. Available from: $<$ http://www.ejbiotechnology.info/index.php/ejbiotechnology/ article/view/v14n6-11/1391>. Accessed: Mar. 22, 2015. doi: 10.2225/vol14-issue6-fulltext-1.

KHARE, S.K.; GUPTA, M.N. Preparation of Concanavalin A-ß-galactosidase conjugate and its application in lactose hydrolysis. J Biosciences, v.13, p.47-54, 1988. Available from: <http://link.springer.com/article/10.1007/BF02832212>. Accessed: Mar. 12, 2015.

KHIDER, K. et al. Purification of water effluent from a milk factory by ultrafiltration using Algerian clay support. Desalination, v.167, p.147-151, 2004. Available from: <http://www.sciencedirect.com/ science/article/pii/S0011916404003650>. Accessed: Mar. 17, 2015. doi: 10.1016/j.desal.2004.06.123.

LADERO, M. et al. Activity over lactose and ONPG of a genetically engineered $\beta$-galactosidase from Escherichia coli in solution and immobilized: kinetic modeling. Enzyme Microb Tech, v.29, p.181-193, 2001. Available from: <http://www.sciencedirect.com/ science/article/pii/S0141022901003660>. Accessed: Mar. 23, 2015. doi: 10.1016/S0141-0229(01)00366-0.

LÓPEZ-GALLEGO, F. et al. Improved stabilization of chemically aminated enzymes via multipoint covalent attachment on glyoxyl supports. J Biotechnol, v.116, p.1-10, 2005. Available from: <http:// www.sciencedirect.com/science/article/pii/S0168165604005073>. Accessed: Mar. 25, 2015. doi: 10.1016/j.jbiotec.2004.09.015.

MLICHOVÁ, Z.; ROSENBERG, M. Current trends of $\beta$-galactosidase application in food technology. J Food Nutr Res, v.5, p.47-54, 2006. Available from: $<$ http:// www.vup.sk/en/ download.php?bulID=8>. Accessed: Mar. 13, 2015.

PANESAR, P.S. et al. Potential applications of immobilized $\beta$ - galactosidase in food processing industries. Enzyme Res, v.2010, p.1-16, 2010. Available from: <http:/www.hindawi.com/ journals/er/2010/473137/ref/>. Accessed: Mar. 22, 2015. doi: $10.4061 / 2010 / 473137$.

PESSELA, C.C.B. et al. The immobilization of a thermophilic $\beta$-galactosidase on Sepabeads supports decrease product inhibition: complete hydrolysis of lactose in dairy products. Enzyme Microb Tech, v.33, p.199-205, 2003. Available from: <http://www. sciencedirect.com/science/article/pii/S0141022903001200>. Accessed: Mar. 17, 2015. doi: 10.1016/S0141-0229(03)00120-0.

PRAZERES, A.R. et al. Cheese whey management: a review. J Environ Manage, v.110, p.48-68, 2012. Available from: $<$ http://www.sciencedirect.com/science/article/pii/ S1369703X11002257>. Accessed: Mar. 28, 2015. doi: 10.1016/j.jenvman.2012.05.018.

$\mathrm{RECH}, \mathrm{R}$. et al. Utilization of protein hydrolyzed cheese-whey for production of $\beta$-galactosidase by Kluyveromyces marxianus. J Ind Microbiol Biotech, v.23, p.91-96, 1999. Available from: $<$ http://link.springer.com/article/10.1038/sj.jim.2900692>. Accessed: Mar. 27, 2015.

SALEEMUDDIN, M.; HUSAIN, Q. Concanavalin A: A useful ligand for glycoenzyme immobilization-a review. Enzyme Microb Technol, v.13, p.290-295, 1991. Available from: $<$ http://www.sciencedirect.com/science/article/ pii/0141022991901462>. Accessed: Mar. 17, 2015. doi: 10.1016/0141-0229(91)90146-2.

SHEN, Q. et al. Gelatin-templated biomimetic calcification for $\beta$-galactosidase immobilization. Process Biochem, v.46, p. 15651571, 2011. Available from: <http://www.sciencedirect.com/ science/article/pii/S135951131100153X>. Accessed: Mar. 23, 2015. doi: 10.1016/j.procbio.2011.04.010.

SISO, M.I.G. The biotechnological utilization of cheese whey: a review. Bioresour Technol, v.57, p.1-11, 1996. Available from: <http://www.sciencedirect.com/science/ article/pii/0960852496000363>. Accessed: Mar. 24, 2015. doi: 10.1016/0960-8524(96)00036-3.

SMITHERS, G.W. Whey and whey proteins from 'gutter-to-gold'. Int Dairy J, v.18, p.695-704, 2008. Available from: <http://www. sciencedirect.com/science/article/pii/S0958694608000344>. Accessed: Mar. 28, 2015. doi: 10.1016/j.idairyj.2008.03.008.

TAVARES, T.G.; MALCATA, F.X. The portuguese paradox: why do some inhabitants of Portugal appear to live so long when their diet is based on whey cheese? Food Chem, v.131, p.727-729, 2012. Available from: <http://www.sciencedirect.com/science/ article/pii/S0308814611013148>. Accessed: Mar. 28, 2015. doi: 10.1016/j.foodchem.2011.09.052.

VASILJEVIC, T.; JELEN, P. Production of galactosidase for lactose hydrolysis in milk and dairy products using thermophilic lactic acid bacteria. Innovat Food Sci Emerg Tech, v.2, p.75-85, 2001. Available from: <http://www.sciencedirect.com/science/ article/pii/S1466856401000273>. Accessed: Mar. 29, 2015. doi: $10.1016 / \mathrm{S} 1466-8564(01) 00027-3$.

VIEIRA, D.C. Imobilização da enzima $\beta$ galactosidase de Kluyveromyces fragilis em agarose e quitosana utilizando diferentes protocolos de ativação. 2009. 115f. Dissertação (Mestrado em Engenharia Química) - Universidade Federal de São Carlos, São Carlos, SP. 